\title{
Internal architecture and mobility of tidal sand ridges in the East China
} Sea

\author{
Zhenxia Liu ${ }^{a^{k}}$, Serge Bernéb, Yoshiki Saito ${ }^{c}$, Hua Yu ${ }^{d}$, Alain Trentesaux ${ }^{e}$, Katsuto Uehara ${ }^{f}$,

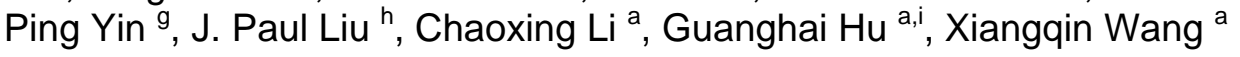 \\ ${ }^{a}$ First Institute of Oceanography, State Oceanic Administration, Qingdao 266061, P. R. China \\ ${ }^{\mathrm{b}}$ Rice University, Houston, TX 77005, USA \\ ${ }^{c}$ Geological Survey of Japan, AIST, Tsukuba 305-8567, Japan \\ d IFREMER, DRO/GM, P. O. Box70, 29280 Plouzané, France \\ e PBDS Laboratory, UMR 8110 CNRS, University of Lille 1, 59655 Villeneuve d'Ascq, France \\ ${ }^{\mathrm{f}}$ DSRC/RIAM, Kyushu University, Kasuga, Fukuoka 816-8580, Japan \\ ${ }^{9}$ Qingdao Institute of Marine Geology, Qingdao 266071, China \\ h Department of Marine, Earth and Atmospheric Sciences, North Carolina State University, Raleigh, \\ NC 27695, USA \\ 'Ocean University of China, Qingdao 266061, P. R. China \\ * Corresponding author: e-mail: liuzhenxia@fio.org.cn
}

\begin{abstract}
:
On the basis of bathymetric and seismic data and data from piston cores collected by the Chinese-French marine geology and geophysics investigation of 1996, we discuss the internal architecture and mobility of tidal sand ridges in the East China Sea (ECS). We characterized the sand ridges on the middle to outer shelf of the ECS as tide-dominated sand ridges with southwest dipping beds, indicating that the regional net sediment transport is toward the southwest. As the sand ridges gradually migrate toward the southwest, new sand ridges are continually replacing old ones, and several generations of sand ridges have developed in the study area.

High-resolution seismic data, acoustic Doppler current profiler data, and two ${ }^{14} \mathrm{C}$-dated piston cores, DGKS9614 and DGKS9612-from a sand ridge swale and crest respectively-show that these sand ridges, which are at water depths of 90-100 m, have been migrating for the last ca. 2-3 ky at least, though these ridges have previously been interpreted as moribund or relict. Sequence stratigraphic interpretation of seismic profiles and core data show that tidal ridges in the ECS evolved from muddier sand ridges formed during the last transgression to sandier shelf sand ridges in response to the shoreline retreat, which resulted in a decrease of riverine muddy sediments and recycling of sandy materials by tidal currents. Most active sand ridge formation occurred during the last transgression, but the present sand ridges on the middle to outer shelf are still being influenced by the modern hydrodynamics. Therefore, these sand ridges on the ECS shelf should be referred to as "quasi-active sand ridges" rather than as moribund or relict sand ridges.
\end{abstract}

Keywords: Tidal sand ridge; Internal architecture; Mobility; East China Sea; Ridge evolution; Transgression 


\section{Introduction}

Tidal sand ridges are a characteristic feature of tide-dominated continental shelves. Their generation requires a source of mobile sediment, either from the local seabed or from coastal erosion (Dyer and Huntley, 1999). Their configuration and geomorphology result from an equilibrium between tidal current dynamics, seafloor morphology, and sediment supply. It is generally accepted that tidal sand ridges are formed at a water depth of less than 30 to $50 \mathrm{~m}$, such as those offshore of Jiangsu in the western Yellow Sea (Liu et al., 1989) and in the western Korean Bay (Off, 1963), the eastern Bohai Sea (Liu et al., 1998), the eastern Yellow Sea (Jung et al., 1998, Park et al., 2006), and the North Sea (Stride, 1982). On the other hand, sand ridges on the outer shelf are usually regarded as relict, inactive, or moribund (Bouysse et al., 1976), having been formed during the last lowstand of sea level or the early phase of the last transgression (e.g., Saito et al., 1998; Park et al., 2006).

There are clear morphological differences between active and relict ridges. Active ridges show superimposed bedform features and an asymmetrical cross section, with a steeper slope having a gradient of up to $6^{\circ}$ and a gentle slope with a $1^{\circ}$ gradient (Stride, 1982). Moribund sand ridges, in contrast, are characterized by smooth and gentle transverse profiles. The steeper slope has a gradient of about $1^{\circ}$, and no sand dunes are superimposed on either flank.

Recently, Park et al. (2006) described two types of sand ridges in the Yellow Sea (YS), modern nearshore sand ridges and shelf sand ridges formed during the last transgression, which differ in morphology, sediment characters, and age. Numerical simulations have also revealed differences between modern sand ridges and those formed during the last transgression in both the East China Sea (ECS) and the YS (Uehara et al., 2002; Uehara and Saito, 2003). The tidal regime during the last transgression was stronger than the modern one; in particular, sea levels about $60-75 \mathrm{~m}$ below that at present resulted in strong tidal stress on the seafloor during the last transgression. Wu et al. (2005) investigated the detailed three-dimensional morphology of the sand ridges on the outer shelf of the ECS on the basis of compiled core data, and concluded that the tide-dominant system during 8-12 ky BP might have played a key role in their formation. Although according to these reports (Uehara et al., 2002; Wu et al., 2005; Park et al., 2006), the sand ridges on the middle to outer shelf in the ECS and YS are at present relict or moribund features, here we discuss sand ridge activity on the middle to outer shelf of the ECS during the late Holocene and the evolution of these sand ridges since the last transgression. On the basis of bathymetric data, Acoustic Doppler Current Profiler (ADCP) measurements, and seismic profiles and core data, we discuss in detail the internal architecture, evolution, and mobility of sand ridges in the ECS during the late Holocene and propose the concept of "quasi-active sand ridges" to describe them. 


\section{Regional setting}

The ECS is one of the shallow marginal seas in the western Pacific Ocean, and it has an area of $773,000 \mathrm{~km}^{2}$. Nearly two-thirds of the seafloor is a broad continental shelf. Fine sediments supplied by large rivers, such as the Yangtze, Qiantang, and Ming rivers, are deposited mainly on the ECS inner shelf (Liu et al., 2006; 2007), forming a nearshore mud belt along the coast. Most of the middle to outer ECS continental shelf is covered by sandy sediments in the form of sand ridges or sand sheets (Bartek and Wellner, 1995; Liu, 1997; Saito et al., 1998; Liu et al., 2000). From offshore of the Yangtze River to the outer continental shelf, the seafloor topography is characterized by undulating ridges, referred to as sand ridges or linear sand ridges, and intervening swales (Fig. 1). Generally, the sand ridges are 8 to $14 \mathrm{~km}$ wide and tens of kilometers long, with the longest ridge about $120 \mathrm{~km}$ long. The sand ridge system in the ECS is controlled mainly by the Pacific Ocean tide-wave system, and at present, as in the past. The crests of the sand ridges are oriented NW-SE, approximately parallel to the major axis of the tidal ellipse (within about $20^{\circ}$ ) and perpendicular to the continental margin. The tidal sand ridges in the ECS compose one of the largest and deepest ridge systems in the world.

Previous studies have shown that the tidal sand ridge system in the ECS formed during the last transgression, but that these sand ridges have now ceased developing and have entered into a moribund or relict phase (Yang and Sun, 1988; Liu et al., 1998; Saito et al., 1998; Berné et al., 2002; Yoo et al., 2002). Two explanations have been offered in support of this interpretation: (1) the tidal current velocities around the sand ridges are rotary and small, only 20-40 cm/s, so they cannot form modern large-scale tidal sand bodies (Fang, 1994); and (2) these sand ridges lack superimposed bedforms, such as sand dunes, on their surface. Yang and Sun (1988) proposed that the tidal sand ridges in the ECS had formed in the paleo-Yangtze estuary during the last transgression (13.5-11 ky BP), when water depths were shallower and the tidal currents were stronger than those of the present day. The active sand ridge field moved landward with the rise in sea level during the last transgression. At present, the sand ridges are composed of relatively sandy Holocene sediments (Saito et al., 1998; Wu et al., 2005) or, in the case of some erosional ridges, relatively muddy sediments (Saito et al., 1998; Berné et al., 2002; Chen et al., 2003). The material of the sand ridges may also derive from the redeposition of Pleistocene fluvial or deltaic sediments (Liu et al., 1998).

Paleotidal current field simulations in the ECS and YS for different sea levels, 45, 60, 75, or $90 \mathrm{~m}$ below the present sea level, show that the tidal current velocity during the sea-level rise was larger than that of the present day, and that the sand ridges were formed at the different present-day water depths as the shoreline retreated (Uehara et al., 2002; Uehara and Saito, 2003). The sand ridges formed at water depths of less than 30-50 m but the depth of the water above the shelf changed as the sea level rose. Therefore active sand ridge field has migrated landward in relation to sea-level rise.

There are two major sand ridge fields on the continental shelf. In addition to the ECS sand ridge field described above, there is a second field is in the eastern part of the YS (Park et al., 2006). Sand ridges in the YS are classified into two types: shelf sand ridges at water depths of 50-90 m, and nearshore sand ridges at water depths shallower than about $30 \mathrm{~m}$. The shelf sand ridges developed mainly during the postglacial transgression (ca. 9.5-14 ky BP), and their morphology is thought to reflect erosional processes acting primarily during the last 
transgression. In contrast, the nearshore sand ridges have been subjected to tidal action under modern conditions for the last $7 \mathrm{ky} \mathrm{BP}$ and show the typical modern erosional sand ridge morphology.

The major difference in the sand ridges between the ECS and YS is that those in the ECS show depositional features and those in the YS show erosional features, caused by differences in the sediment supply. The huge sediment supply from the Yangtze River might have allowed the depositional ridge system to form on the shelf in the ECS (Yang and Sun, 1988; Liu et al., 1998; Saito et al., 1998; Berné et al., 2002).

\section{Methods}

The ECS data were collected by the Chinese-French marine geology and geophysics investigation during a cruise of the French R/V L'Atalante in 1996, including bathymetric data by a EM 950 multibeam echosounder system; seismic profiles by a $700 \mathrm{~J}$ SIG sparker (200-600 Hz) (Fig. 2); current data measured by ADCP, and piston cores (Liu et al., 2000; Berné et al., 2002). A Global Positioning System (GPS) instrument was used during the investigation, providing accuracy within $10 \mathrm{~m}$. Accuracy with $5 \mathrm{~m}$ was obtained by differential GPS in the detailed mapping of a small area. Digital data were acquired and processed onboard with a Delph 2 system. Data were post-processed with the SITHERE software package (Lericolais et al., 1990). ADCP measurements were acquired during the detailed mapping of a small area (Fig. 2, right panel) where the average water depth was $90 \mathrm{~m}$ (centered at $29^{\circ} \mathrm{N}, 125^{\circ} 15^{\prime} \mathrm{E}$ ). The observed tidal current velocity was compared with tidal predictions obtained from a two-dimensional numerical simulation. The tidal model used in this study was same as that of Uehara and Saito (2003), except that the number of constituents was increased from six $\left(M_{2}, S_{2}, K_{1}, O_{1}, N_{2}\right.$, and $\left.M_{4}\right)$ to $12\left(M_{2}, S_{2}, K_{1}, O_{1}, N_{2}, P_{1}, K_{2}, Q_{1}, M_{4}\right.$, $\mathrm{MS}_{4}, \mathrm{M}_{3}$, and $\mathrm{M}_{6}$ ) and the ocean tides predicted by Matsumoto et al. (2000) were adopted as open-boundary forcing.

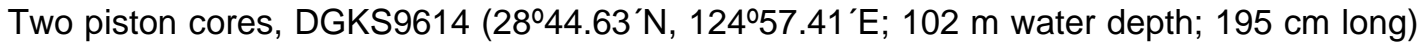
and DGKS9612 (28 ${ }^{\circ} 44.29^{\prime} \mathrm{N}, 125^{\circ} 00.318^{\prime} \mathrm{E} ; 85 \mathrm{~m}$ water depth; $373 \mathrm{~cm}$ long), were recovered from the swale and crest, respectively, of a sand ridge (Fig. 2). We carried out a grain-size analysis, measured the carbonate content, performed a paleontological analysis of core DGKS9614, and carried out a grain-size analysis of core DGKS9612. ${ }^{14} \mathrm{C}$ dates were obtained on mollusc shells by accelerator mass spectrometry (AMS) through Beta Analytic (Miami, FL, USA) and at Lawrence Livermore National Laboratory (LLNL; Livermore, CA, USA). These data are reported as conventional ${ }^{14} \mathrm{C}$ ages in this paper.

\section{Results}

\subsection{Hydrodynamics}

The ADCP measurements indicated that current velocities reached $55 \mathrm{~cm} / \mathrm{s}, 1 \mathrm{~m}$ above the sea floor (Fig. 3a), during a period of fair weather and under intermediate to neap tide conditions, during a transition period from a spring to a neap tide (7-9 May 1996) (Berné et al., 2002). Periods of high current velocity toward the N-NW were followed $12 \mathrm{~h}$ later by the lowest current velocity toward the S-SE, and were attributed to the $\mathrm{M}_{2}$ tide. Current velocity tended to be low from periods of low water (LW) to those of high water (HW), and high during HW periods 
until the following LW period (Fig 3a). Tidal modeling results suggest that secondary components such as the $\mathrm{S}_{2}, \mathrm{~K}_{1}, \mathrm{O}_{1}$, and $\mathrm{N}_{2}$ constituents modulated the basic $\mathrm{M}_{2}$ tidal current (estimated amplitude, $38 \mathrm{~cm} / \mathrm{s}$ at the ADCP site) to produce high tidal velocities exceeding 50 $\mathrm{cm} / \mathrm{s}$ during the observation period (Fig. 3b), and velocities of more than $60 \mathrm{~cm} / \mathrm{s}$ during a spring tide (Fig. 3c). Observed and predicted currents are further compared in section 5.1.

\subsection{Piston core analysis}

Piston core DGKS9614 could be divided into three distinct sections: layers A, B, and C from the top (Fig. 4). Layer A $(0-75 \mathrm{~cm})$ is composed of well-sorted, dark gray very-fine-to-fine sand; almost no clay and little coarse silt are present in this layer, and it contains only a few shells. The carbonate content is about 8\%. Layers B $(75-139 \mathrm{~cm})$ and C (139-199 cm) are composed mainly of fine gray sand intercalated with muddy laminae. Clay and silt contents are clearly higher than those of layer A. Layer B contains abundant shells of snails and clams, such as Mactra chinensis (Philippi), Glycymeris rotunda (Dunker), Onustus exuta (Reeve), Nassarius sp., Barbatia sp., Dosinia derupta (Römer), Anisocorbula cuneata (Hinds), Corbula sp., Chione sp., Mornula sp., Natica sp., and Rissoa sp. The carbonate content is about $12 \%$, obviously higher than that in layers A or C. AMS ${ }^{14} \mathrm{C}$ ages from layer B are $2670 \pm 50$ y BP $(84-86 \mathrm{~cm}$, Nassarius sp., Beta-106406); $4210 \pm 60$ y BP (99 cm, Onustus exuta, Beta-106407); and 8180 \pm 70 y BP (136-138 cm, Pecten sp., Beta-106408).

The lithology of core DGKS9612 is homogeneous, consisting of loose gray-yellow medium sand (Fig. 5), coarser than the sand of the adjacent swale. A few shells and clayey pebble clasts are present in the layer at $270-300 \mathrm{~cm}$ depth, which is composed mainly of fine sand. The semi-cemented clayey pebbles are $0.5-1 \mathrm{~cm}$ in size; the largest, at $280 \mathrm{~cm}$ depth, was 2 $\mathrm{cm}$. One $\mathrm{AMS}{ }^{14} \mathrm{C}$ age of $535 \pm 40$ y BP (LLNL) was obtained on bivalve shells from $320-330$ $\mathrm{cm}$.

\subsection{Seismic records}

The high-resolution seismic record profiles acquired in the study area, which cover a total distance of $4380 \mathrm{~km}$, show several sequences of sediments deposited during the last $300 \mathrm{ky}$. These consist of three elementary sedimentary facies: regressive marine prodeltaic wedges, estuarine and continental (deltaic) facies, and transgressive sand ridges (Berné et al., 2002). The sand ridge seismic unit, which formed since the last glacial maximum (LGM), has been referred to as U 2 (Liu et al., 2000), U140a and U140b (Berné et al., 2002), and Unit 3 (Wu et al., 2005). Here, it is called U2, and it comprises several subunits (U2.1 to U2.4; Fig. 6a). Liu et al. (2000) interpreted U2.1 (Fig. 6a) as dating to before the LGM and designated it as U3.1, whereas Berné et al. (2002) interpreted it as an early phase sand ridge unit (U140a) formed after the LGM. Here, we follow the latter interpretation. Most cross sections of the sand ridges in the ECS are asymmetrical, with the steeper slope inclined toward the SW-SSW (Figs. 6a, 8, 9). 


\section{Discussion}

\subsection{Internal architecture of the sand ridges and interpretation of the hydrodynamics}

The internal structures of sand ridges can reflect both the agent of deposition and their process of development. Thus, we first discuss the mechanism of origin of sand ridges with respect to their internal structures. A striking feature of the transverse profiles of the sand ridges is that their interior foreset beds dip SW, parallel to the steeper slope of the sand ridges. The maximum angle of dip is $6^{\circ}$, and most dips are between $2^{\circ}$ and $3^{\circ}$. The bottomset on the lee side may extend hundreds of meters with a very small angle of dip. In longitudinal section, most bedding planes are approximately horizontal, with some inclined toward the SE or NW (Fig. 6b).

Two peculiar tidal hydrodynamic conditions of the ECS may explain the internal bedding structure. One is the flow conditions along the major axis of the tidal currents, which are generally considered to be ebb-dominant over the offshore ECS shelf (Wu et al., 1998), with the major axis direction slightly clockwise relative to the long axes of the sand ridges. Under such circumstances, one flank of a sand ridge mainly faces the flood-tidal current and the other the ebb-tidal current. The result is a gentle eroding slope on the ebb-current-dominated side and a steep accumulating slope on the flood-tide side, causing the transverse profile of the sand ridges to be asymmetric. Because sediments are generally transported from the gentler slope of a ridge to the steeper slope, resulting in internal reflectors paralleling the surface of the steeper flank of the ridge (Johnson and Baldwin, 1996), the net sediment transport is to the southwest. The sand ridges in the ECS continuously migrate toward the SW, thus forming the master bedding inclined toward the SW (Fig. 7), which characterizes the internal structure of tide-dominated sand ridges. At the ADCP site, the ebb current is slightly stronger than the flood (by less than 1\%), and the $\mathrm{M}_{2}$ major axis is $7.2^{\circ}$ clockwise relative the longitudinal trend of the sand ridges $\left(116^{\circ}\right.$ clockwise from north; Wu et al., 2005).

The other possible mechanism would be a secondary tidal current perpendicular to the major current axis. At the ADCP site, the model predicts that the maximum spring-tide velocity has been stronger by $10.5 \%$, on average, toward the SW $\left(213.2^{\circ}\right.$, perpendicular to the $M_{2}$ major axis) than toward the NE $\left(33.2^{\circ}\right)$ during 204 out of 242 spring tides from 1996 to 2005 (Fig. 3c). This stronger southwestward tidal current may contribute to the net sediment transport toward the SW.

Comparison of the ADCP data with the model results suggests that tidal signals in the observed currents may have been obscured by nontidal flows at certain periods. The model reproduces observed currents well for the zonal component, whereas the observed meridional velocities shift northward of the predicted values after 8 May (Fig. 3b), indicating flood-tide dominance, contrary to our previous discussion based on model analyses. This discrepancy in the meridional velocity can be attributed to a change in subtidal flows, because general ocean circulation model results suggest the occasional occurrence of oceanic currents as strong as $15 \mathrm{~cm} / \mathrm{s}$ toward the NNW-NE at the ADCP site (Miyazawa and Yamagata, 2003). The discrepancy may also be caused by tidal rectification due to the local bathymetry, which was not resolved in previous ECS tidal models. It is notable that the site of the ADCP measurements was in a swale between sand ridges (Berné et al., 2002), which may have had 
some effect on the observed flow field. More long-term ADCP observation records, including during spring tides, are needed for further discussion.

As the sediments are transported and the sand ridges migrate toward the SW, new sand ridges continually replace old ones, and several generations of sand ridges have developed in the ECS. That is an autocyclic process of sand ridge development. Some erosion surfaces are present within the sand ridges, showing that younger ridges are superimposed on older ones, resulting in a complicated multilayer architecture that reflects repeated accumulation-erosion-accumulation cycles (Liu et al., 2003). For instance, along seismic profile DS46, there are two to four subunits composing a sand ridge (Fig. 6a). U2.1 (cored sand ridges U140a of Berné et al., 2002) may be the oldest one in which foreset beds are preserved; U2.2 is younger than U2.1, and only the bottomsets are shown in this profile; U2.3 and U2.4 are the second-youngest and the youngest subunits, respectively, and both show foreset beds. It is an important point that autocyclic processes predominate in the overall architecture of the sand ridges in the ECS. Since the last transgression, the sand ridges have migrated gradually toward the southwest. It has been proposed that every migration episode occurs on the base of a preexisting sand ridge, which thus becomes the precursor of the new ridge (Snedden and Dalrymple, 1999). These processes may create an erosion surface between the precursor and the successor. When the new sand ridge migrates to the swale of the older one, a boundary surface is formed.

The sand ridges can be eroded by external forces as well, causing the formation of erosion surfaces within these features. Step-like global sea-level rises can influence sand ridge evolution. Periods of rapid or slow sea-level rise play an important role in sand ridge formation. In particular, rapid rises in sea level have erosive impacts on sand ridges. Sand ridge formation is favored by slow rises in sea level. The internal architecture of the sand ridges in the ECS suggest that some ridges have been affected by erosion (Saito et al., 1998; Berné et al., 2002; Liu et al., 2003; Chen et al., 2003) (Fig. 8), similar to those observed in the Celtic Sea (Reynaud et al., 2003) and the east central YS (Jin and Chough, 2002; Park et al., 2006). Of the sand ridges in the ECS, sand ridges showing evidence of erosion or reaccumulation occupy one-sixth and two-thirds, respectively, of the sand ridge field (Liu et al., 2003).

Typhoons, winter storms, and episodic waves, especially tsunamis caused by underwater earthquakes, are other external forces that can act on sand ridges. All of these external factors probably played a destructive role with respect to ridge growth and caused the formation of erosion surfaces within tidal sand ridges.

\subsection{Age of the sand ridges}

The seismic profiles of the sand ridges suggest that they are composed of strata from several meters to tens of meters thick, with the thickest being up to $26 \mathrm{~m}$ at the ridge crest. Strata are thin in the swales, and in some places old, relict strata are exposed (Saito et al., 1998; Liu et al., 2000). Piston core DGKS9614 was recovered from a sand ridge swale. The top layer, A, is composed of sand that is mobile in the modern hydrodynamics environment. Its age is younger than 2000 years, maybe only hundreds of years, and it corresponds to the thin sand veneer reported by Bartek and Wellner (1995) and Berné et al. (2002) on top of the ECS sand ridges. The thickness of this sand layer is generally less than 1 to $2 \mathrm{~m}$, and it ranges from $0.15 \mathrm{~m}$ to $5.5 \mathrm{~m}$ in thickness (Yang, 2002). The bottom boundary of this layer is usually 
undulating with ridges and swales, and the layer unconformably overlies the layer below. The most common explanation for this layer is alteration of surface sediments by modern tidal currents (Berné et al, 2002). It is in equilibrium with the modern hydrodynamic environment and subject to tidal current action. In layer $\mathrm{B}$, the ages were obtained from snail and clam shells; these taxa are characteristic of an intertidal, subtidal, or shallow-marine environment, and therefore the shells were probably transported by storms from the coastal zone. Storm shell beds have been reported from offshore of the Yangtze River mouth at 50-60 m water depth (Wang et al., 2005). The lithology of layer C is similar to that of layer B except that it contains fewer shells.

Although core DGKS9612, which was recovered from the ridge crest, is short and only reflects hundreds of years of deposition history, it provides very meaningful information about the mobility and age of ridges. The thickness of the sand ridges at the DGKS9612 site is about $13.5 \mathrm{~m}$, based on the seismic records (Fig. 9). Because $\mathrm{a}^{14} \mathrm{C}$ age of $535 \pm 40$ y BP (ca. $180 \mathrm{cal}$ y BP) was obtained from $3.3 \mathrm{~m}$ depth in the DGKS9612 core, from the top part of the sand ridge crest, the basal age of the sediment at the bottom of the ridges should be less than 1000 $\mathrm{yr} \mathrm{BP}$, if the accumulation rate did not change very much. This age and the series of ridges migrating toward the SW (Fig. 9) indicate that these sand ridges are still active and that the sands have been deposited concordant with the ridge morphology. The morphological features of these sand ridges (Fig. 9, right side) differ from those of the typical sand ridges, which have steep, SW-dipping foresets. Instead, they show gentle foresets on their SW flanks and erosional features on their NE flanks, which might imply a low sediment supply and slow migration.

The DGKS9611 core, taken from a ridge about $7 \mathrm{~km} \mathrm{NE}$ of the DGKS9612 core (see Fig. 9), shows a surficial $85-\mathrm{cm}$-thick sand layer, and a ${ }^{14} \mathrm{C}$ age of 2430 y BP was obtained at $40 \mathrm{~cm}$ depth (denoted DG11 by Berné et al., 2002). This surficial layer is correlative with modern sand ridge sediments: layer A in DGKS9614 and the 3-m-thick sand bed at the top of DGKS9612. The underlying unit, from $0.85 \mathrm{~m}$ to $7.5 \mathrm{~m}$ depth in DGKS9611, consists of sand-mud tidal rhythmites with ${ }^{14} \mathrm{C}$ ages of $10-11$ ky BP (Berné et al., 2002). Therefore, the main part of the SW-dipping clinoforms at the DGKS site, shown in Fig. 9, must consist of such latest Pleistocene tidal rhythmites. However, the modern 3-m-thick sand bed at DGKS9612 constitutes a sand ridge. There is no obvious erosional surface in the sand ridges between the two sites. A similar problem regarding age and facies has been reported for a ridge from the outer continental shelf of the ECS by Saito et al. (1998). Most ${ }^{14} \mathrm{C}$ ages from a muddy facies below the surficial $30-\mathrm{cm}$-thick sand are older than $20 \mathrm{ky} \mathrm{BP}$, but the ${ }^{14} \mathrm{C}$ ages on planktonic forams, benthic foraminiferas, and molluscs are 3900 y BP, 7260 y BP, and 9190 y BP, respectively (Saito et al., 1998). Therefore, the ${ }^{14} \mathrm{C}$ ages reported from the lower unit of DGKS9611 might not be reliable. We need more ages from muddy sediments in the sand ridges.

Previously reported ages of ridge formation are 8-12 ky BP on the outer shelf (Wu et al., 2005), and 7-8 ky BP on the inner shelf (Chen et al., 2003). Except for the erosional ridges on the outer shelf (Saito et al., 1998; Liu et al., 2000), the ${ }^{14} \mathrm{C}$ ages of the sandier sand ridges on the middle shelf at water depths of 90-110 m are 5-8 ky BP (Saito et al., 1998) and less than 2-3 ky BP (this study). This problem is further discussed below in relation to ridge evolution. 


\subsection{Mobility of the sand ridges}

In our detailed study area (Fig. 2 right), we measured current velocities of $55 \mathrm{~cm} / \mathrm{s}$ near the bed during fair weather, under medium neap-tide conditions. This indicates that current velocity values should be much higher in spring-tide periods, especially when combined with wave orbital velocities generated by major storms or at shallower depths. This also implies that the velocity of the current is larger than we originally thought it could be. These current velocities are sufficient for the bedload transport of the fine-to-medium sands that blanket most of the ECS outer continental shelf. Butenko et al. (1983a) estimated that surficial tidal currents are faster than $100 \mathrm{~cm} / \mathrm{s}$ on the inner shelf and can reach $75 \mathrm{~cm} / \mathrm{s}$ at the shelf edge in the ECS. These velocities suggest that tidal currents still act to some extent on the sand ridge field. Belderson et al. (1982, Table 3.4) pointed out that the currents associated with moribund sand ridges have velocities that are generally less than $50 \mathrm{~cm} / \mathrm{s}$. Butenko et al. (1983a) and also our current data show velocities greater than this value, suggesting, therefore, that the modern tidal hydrodynamics can erode and transport the unconsolidated sediments on the seafloor of the ECS. Thus, the ridges may still be active under present-day conditions, if only during high-energy events. Thus, these sand ridges are not completely moribund. Modern tidal currents play a maintaining, modifying, and even constructing role in sand-ridge development in the ECS. The morphological and internal features shown in Figure 9 differ from those of typical active sand ridges, possibly indicating that these ridges are in a state between active and moribund.

Almost no large sand dunes were observed on the surface of the sand ridges in the ECS during the 1996 investigation except in the active Yangtze Shoal Sheet (Butenko et al., 1983b; Liu, 1997), which implies that the sand ridges are not in a very active state and that the present-day seabed does not correspond to the main ridge-building phase. Nevertheless, some seismic profiles show that some of the sand ridges are exposed to erosion and are somewhat active.

Additionally, the transverse profiles of the sand ridges are asymmetrical, smooth, and gentle; overall, the angles of dip of the steeper slopes are around $1^{\circ}$, and the maximum angle of dip is $2.1^{\circ}$, whereas the angle of dip of the gentle slopes is mostly less than $1^{\circ}$. Generally, the transverse profile of a moribund sand ridge is relatively gentle, with a steep slope of $1^{\circ}$ and a gentle slope of $0.5^{\circ}$. The dip angles of the sand ridges in the ECS are thus less than those of typical active sand ridges and more than those of moribund sand ridges (Fig. 10). The transverse profiles of the sand ridges in the ECS thus fit the picture of sand ridges between an active and moribund state.

The lack of superimposed sand dunes on the ECS sand ridges has resulted in their being classified as moribund ridges. However, from the viewpoints of modern hydrodynamics, sediment characteristics, ridge configuration, and ${ }^{14} \mathrm{C}$ dates of the sand ridges, the sand ridges seem to be still active. Therefore, we propose that properly speaking, most of the sand ridges are in a transitional stage between active and moribund and can be referred to as "quasi-active sand ridges" instead of as moribund ridges.

Milliman (1972) regarded modern deposition to mean sediments deposited since the end of the last period of continuous sea-level rise. That must be the definition of modern deposition in a broad sense. Most scholars now agree that sea level reached a highstand at about 6-7 ky $\mathrm{BP}$ and since then has remained relatively steady. This suggests that the hydrodynamic 
environment has remained relatively stable as well. However, in estuaries, nearshore areas, and shallow seas, where high sedimentation rates and strong currents and waves have occurred over a relatively long period, the regional hydrodynamic environment has changed since then. For example, the shoreline of the Yangtze delta has migrated more than $250 \mathrm{~km}$ seaward during the last 7 ky (Saito et al., 2001; Hori et al., 2001), and the physical oceanography of the coastal zone has changed greatly as a result of the coastline change (Uehara et al., 2002). However, these changes have had a large impact only in the coastal zone. Tidal stress has slightly decreased or remained stable on the middle to outer shelf during this period (Uehara et al., 2002).

\subsection{Sand ridge evolution and synthesis}

From the above analyses, it is reasonable to regard the last transgression as the construction epoch of the tidal sand ridges. When sea level rose slowly or remained relatively stable, initial tidal sand ridges formed in estuarine or offshore areas in the present outer shelf area. As sea level continued to rise, the sediments on the seafloor were eroded, transported, and redeposited under the tidal current action. The bedforms adjusted gradually to the varying hydrodynamic environment, and the sand ridges probably lost some of their original characteristics. This scenario agrees with the interpretation of Dyer and Huntley (1999), who pointed out that most of the sand ridges appear to have been created during the postglacial rise of sea level, and were subsequently modified by changing currents and waves, thus losing their original characteristics. As shown in Figure 6, a stacked sand ridge system formed during the last transgression in the ECS. Therefore, some sand ridges of earlier phases might be preserved in the lower part of the stacked section, owing to the mainly high sediment supply and the adequate accommodation space here.

The original or earlier sand ridges might have consisted of relatively muddier sediments because of the huge muddy sediment supply from the Yangtze River. However, reworking during the transgression has produced sand ridges composed of relatively sandier sediments and has transported the fine sediments from the surrounding shelf area and the continental slope to the Okinawa Trough, recorded as high accumulation rates on the slope during the last transgression (Oguri et al., 2000). Moreover, a numerical simulation shows that stronger tidal stress occurred on the seafloor when sea level was lower, about 60 to $75 \mathrm{~m}$ below the present level, during the last transgression (Uehara and Saito, 2003).

Taking into account the local relative postglacial sea-level history (Hori et al., 2002; Liu et al., 2004; Xiao et al., 2004) and the relationship between the spacing of sand ridges and water depth reported by Huthnance (1982), along with the observed average sand ridge spacing of 8-14 km, we calculated that the sand ridges of the ECS were originally formed in a shallow marine environment at 32-56 m water depth during the last sea-level rise (about 9-11 ky BP). These sand ridges were the first formed on the open continental shelf. Before this time, sand ridges in the ECS were associated mainly with estuaries (Yang and Sun, 1988), which received lots of fine sediment from the paleo-Yangtze River. After 9-11 ky BP, sand ridges in the ECS were continually modified and migrated southwestward, to be replaced by new ones.

Stacking of sand ridges might imply step-like sea-level rises. Yoo et al. (2002) reported a simple stratigraphy and depositional/erosional model for the northern part of the ECS. They applied a wave-dominated shelf model (e.g., Saito, 1994) to the ECS shelf incorporating a 
single ravinement surface formed by shoreface erosion during the last transgression. However, as shown by the stacked sand ridge system and the present "quasi-active sand ridges" evidence, sediment dynamics and strata formation on the ECS continental shelf have been dominated by strong tides, more than by waves, from the LGM to the present. Therefore, a new model for tide-dominated shelves must be employed.

The sand-ridge units in the seismic records are several meters to $26 \mathrm{~m}$ thick at maximum. However, the surficial sand facies forming sand ridges are only $5.5 \mathrm{~m}$ thick at maximum (Yang, 2002), and the underlying facies are muddy sand to mud. Therefore, some of the sand ridges shown in the seismic records consist of muddier sediment facies. Obviously recycled sand has formed sandier sand ridges during the last 6-7 ky (shown in Figs. 4, 5, and 9). However, we do not have enough data on muddier ridges or muddy sediment distribution for the same period. At least layers B and C of DGKS9614 show muddier sediment facies with ${ }^{14} \mathrm{C}$ ages of 2-8 ky $\mathrm{BP}$, indicating that muddier sediments were also deposited in the middle to outer shelf area. We need more information on both "quasi-active sand ridges" and the relatively tide-influenced muddier sand ridges formed at the same time.

\section{Conclusion}

The sand ridges in the ECS are tide-dominated sand ridges whose internal structures are characterized by southwest-dipping beds, indicating that the regional net sediment transport is toward the southwest. Two piston cores, DGKS9614 and DGKS9612, taken from a sand ridge swale and crest, respectively, and ADCP current data show sand deposition forming sand ridge morphology during the late Holocene and enough tidal current velocity at the seafloor for sediment transport.

Taking into account the modern hydrodynamics, sediment characteristics, ridge configuration, and tidal sand ridge development in the ECS, we propose that the sand ridges are still active to some extent, and we refer to them as "quasi-active sand ridges" instead of as moribund sand ridges as they have been previously described. Most sand ridges appear to have been in equilibrium with the modern hydrodynamics since 6 to $7 \mathrm{ky}$ BP.

Sand ridges in the ECS have evolved since the last transgression and subsequent stable sea level during the last 6-7 ky. Muddier sand ridges during the transgression have evolved into sandier sand ridges by reworking and recycling of sandy materials during the last 6-7 ky. Modern tidal stress on the seafloor has impacted not only areas with less than $50 \mathrm{~m}$ water depth but also those at a water depth of at least 90-100 m.

\section{Acknowledgements}

The authors are thankful to the scientific and technical teams of IFREMER and GENAVIR, on L'Atalante in 1996. This work was financially supported by the National Natural Science Foundation of China (Grant nos. 40421150011, 40176016) and the Ministry of Science and Technology of China (No. 2003cb716706). We thank Xiutong Ma, Hong Ren, and Huiyan Wang for identifying mollusks and particle size analysis of the DGKS9614 core samples. We are very grateful to editor Dr. Richard Sternberg and two reviewers for their review of the manuscript and helpful comments. 


\section{References}

Bartek, L.R., Wellner, R.W., 1995. Do equilibrium conditions exist during sediment transport studies on continental margins? An example from the East China Sea. Geo-Marine Letters 15 (1), 23-29.

Belderson, R.H., Johnson, M.A., Kenyon, N.H., 1982. Bedforms. In: Stride, A.H. (Ed.), Offshore Tidal Sands: Processes and Deposits. Chapman \& Hall, London, pp. 27-57.

Berné, S., 1996. Donghai Cruise Preliminary Report. IFREMER/DRO/GM Report, pp. 32-33.

Berné, S., Vagner, P., Guichard, F., Lericolais, G., Liu, Z.X., Trentesaux, A., Yin, P., 2002. Pleistocene forced regressions and sand ridges in the East China Sea. Marine Geology 188 (3-4), 293-315.

Bouysse, P., Horn, R., Lapierre, F., LeLann, F., 1976. Etude des grands bancs de sable du Sud-Est de la Mer Celtique. Marine Geology 20(3), 251-275.

Butenko, J., Milliman, J.D., Ye Y.C., 1983a. Geomorphology, shallow structure, and geological hazards in the East China Sea. Continental Shelf Research 4 (1-2), 121-141.

Butenko, J., Yincan, Y., Milliman, J.D., 1983b. Morphology, sediments and Late Quaternary history of the East China Sea. In: Jin, Q.M., Milliman, J.D. (Eds.), Sedimentation on the Continental Shelf with Special Reference to the East China Sea. China Ocean Press, Beijing, pp. 653-677.

Chen, Z.Y., Saito, Y., Hori, K., Zhao, Y.W., Kitamura, A., 2003. Early Holocene mud-ridge formation in the Yangtze offshore, China: a tidal-controlled estuarine pattern and sea-level implications. Marine Geology 198 (3-4), 245-257.

Dyer, K.R., Huntley, D.A., 1999. The origin, classification and modeling of sand banks and ridges. Continental Shelf Research 19 (10), 1285-1330.

Fang, G.H., 1994. Tides and tidal currents in East China Sea, Huanghai Sea and Bohai Sea. In: Zhou D., Liang, Y.B., Zeng, C.K. (Eds.), Oceanology of China Seas. Vol. 1, Kluwer Academic Publisher, pp. 101-112.

Hori, K., Saito, Y., Zhao, Q., Cheng, X., Wang, P., Sato, Y., Li, C., 2001. Sedimentary facies and Holocene progradation rates of the Changjiang (Yangtze) delta, China. Geomorphology 41 (2-3), 233-248.

Hori, K., Saito, Y., Zhao, Q., Wang, P., 2002. Evolution of the coastal depositional systems of the Changjiang (Yangtze) river in response to late Pleistocene-Holocene sea-level changes. Journal of Sedimentary Research 72(6), 884-897.

Huthnance, J.M., 1982. On one mechanism forming linear sandbanks. Estuarine and Coastal Marine Science 14 (1), 19-99.

Jin, J.H., Chough, S.K., 2002. Erosional shelf ridges in the mid-eastern Yellow Sea. Geo-Marine Letters 22 (4), 219-225.

Johnson, H.D., Baldwin, C.T., 1996. Shallow clastic seas. In: Reading, H. G. (Ed.), Sedimentary environments: processes, facies and stratigraphy. Blackwell, Cambridge, MA, pp. 232-280.

Jung, W.Y., Suk, B.C., Min, G.H., Lee, Y.K., 1998. Sedimentary structure and origin of a mud-cored pseudo-tidal sand ridge, eastern Yellow Sea, Korea. Marine Geology 151 (1-4), 73-88.

Kenyon, N.H., Belderson, R.H., Stride, A.H., Johnson, M.A., 1981. Offshore tidal sand banks as indicators of net sand transport and as potential deposits. In: Nio, S.D., 
Schuttenhelm, R.T.E., Van Weering, T.C.E. (Eds.), Holocene Marine Sedimentation in the North Sea Basin. International Association of Sedimentologists Special Publication no. 5, 257-268.

Lericolais, G., Allenou, J.P., Berné, S., Morvan, P., 1990. A new system for acquisition and processing of very high-resolution seismic reflection data. Geophysics 55 (8), 1036-1046.

Liu, J.P., Milliman, J.D., Gao, S., Cheng, P., 2004. Holocene development of the Yellow River's subaqueous delta, North Yellow Sea. Marine Geology 209 (1-4), 45-67.

Liu, J.P., Li, A.C., Xu, K.H., Velozzi, D.M., Yang, Z.S., Milliman, J.D., DeMaster, D.J., 2006. Sedimentary features of the Yangtze River-derived along-shelf clinoform deposit in the East China Sea. Continental Shelf Research 26 (17-18), 2141-2156.

Liu, J.P., Xu, K.H., Li, A.C., Milliman, J.D., Velozzi, D.M., Xiao, S.B., Yang Z.S., 2007. Flux and Fate of Yangtze River Sediment Delivered to the East China Sea. Geomorphology, 85 (3-4), 208-224.

Liu, Z.X., 1997. Yangtze Shoal-a modern tidal sand sheet in the northwestern part of the East China Sea. Marine Geology 137 (3-4), 321-330.

Liu, Z.X., Huang, Y.C., Zhang, Q.N., 1989. Tidal current ridges in the southwestern Yellow Sea. Journal of Sedimentary Petrology 59 (3), 432-437.

Liu, Z.X., Xia, D.X., Berné, S., Wang, K.Y., Marsset, T., Tang, Y.X., Bourillet, J.F., 1998. Tidal-depositional systems of China's continental shelf, with special reference to the eastern Bohai Sea. Marine Geology 145 (3-4), 225-253.

Liu, Z.X., Berné, S., Saito, Y., Lericolais, G., Marsset, T., 2000. Quaternary seismic stratigraphy and paleoenvironments on the continental shelf of the East China Sea. Journal of Asian Earth Sciences 18 (4), 441-452.

Liu, Z.X., Yin, P., Xiong, Y.Q., Berné, S., Trentesaux, A., Li, C.X., 2003. Quaternary transgressive and regressive depositional sequences in the East China Sea. Chinese Science Bulletin 48 (Supp.), 81-87.

Matsumoto, K., Takanezawa, T., Ooe, M., 2000. Ocean tide models developed by assimilating TOPEX/POSEIDON altimeter data into hydrodynamical model: a global model and a regional model around Japan. Journal of Oceanography 56(5), 567-581.

Milliman, J.D., 1972. Atlantic continental shelf and slope of the United States-petrology of the sand fraction of sediments, northern New Jersey to southern Florida. US Geological Survey Professional Paper 529-J, $40 \mathrm{p}$.

Miyazawa, Y., Yamagata, T., 2003. The JCOPE ocean forecast system. Kaiyo Monthly 35(12), 881-886 (in Japanese).

Off, T., 1963. Rhythmic linear bodies caused by tidal currents. American Association of Petrology and Geology. Bulletin 47 (2), 324-341.

Oguri, K., Matsumoto, E., Saito, Y., Honda, M.C., Harada, N., Kusakabe, M., 2000. Evidence for the offshore transport of terrestrial organic matter due to the rise of sea level: The case of the East China Sea continental shelf. Geophysical Research Letters 27, 3893-3896.

Park, S.C., Lee, B.H., Han H.S., Yoo, D.G., Lee, C.W., 2006. Late Quaternary stratigraphy and development of tidal sand ridges in the eastern Yellow Sea. Journal of Sedimentary Research 76 (9), 1093-1105. 
Reynaud, J.-Y., Tessier, B., Auffret, J.P., Berné, S., De Batist, M., Marsset, T., Walker, P., 2003. The offshore Quaternary sediment bodies of the English Channel and its Western Approaches. Journal of Quaternary Science 18(3-4), 361-371.

Saito, Y., 1994. Shelf sequence and characteristic bounding surfaces in a wave-dominated setting: Latest Pleistocene-Holocene examples from Northeast Japan. Marine Geology 120 (1-2), 105-127.

Saito, Y., Katayama, K., Ikehara, K., Kato, Y., Matsumoto, E., Oguri, K., Oda, M., Yumoto, M., 1998. Transgressive and highstand systems tract and post-glacial transgression, the East China Sea. Sedimentary Geology 122 (1-4), 217-232.

Saito, Y., Yang, Z., Hori, K., 2001. The Huanghe (Yellow River) and Changjiang (Yangtze River) deltas: a review on their characteristics, evolution and sediment discharge during the Holocene. Geomorphology 41(2-3), 219-231.

Snedden, J.W., Dalrymple, R.W., 1999. Modern shelf sand ridges: from historical perspective to a unified hydrodynamic and evolutionary model. In: Bergman, K.M., Snedden, J.W. (Eds.) Isolated shallow marine sand bodies: Sequence stratigraphic analysis and sedimentologic interpretation. SEPM Special Publication, no. 64, pp. 13-28.

Stride, A.H. (Ed.), 1982. Offshore tidal sands, processes and deposits. Chapman and Hall, London, $222 \mathrm{p}$.

Uehara, K., Saito, Y., 2003. Late Quaternary evolution of the Yellow/East China Sea tidal regime and its impacts on sediment dispersal and seafloor morphology. Sedimentary Geology 162 (1-2), 25-38.

Uehara, K., Saito, Y., Hori, K., 2002. Paleotidal regime in the Changjiang (Yangtze) Estuary, the East China Sea at $6 \mathrm{ka}$ and $10 \mathrm{ka}$ estimated from a numerical model. Marine Geology 183 (1-4), 179-192.

Wang, Z.H., Saito, Y., Hori, K., Kitamura, A., Chen, Z.Y., 2005. Yangtze offshore, China: highly laminated sediments from the transition zone between subaqueous delta and the continental shelf. Estuarine, Coastal and Shelf Science 62 (1-2), 161-168.

Wu, Y.C., Huang, H.J., Yang, Y.L., 1998. Hydraulic dynamical effect on the formation and evolution processes of the deltaic sand banks off northern Jiangsu Coast. Studia Marina Sinica (40), 55-63.

Wu, Z.Y., Jin, X.L., Li, J.B., Zheng, Y.L., Wang, X.B., 2005. Linear sand ridges on the outer shelf of the East China Sea. Chinese Science Bulletin 50 (21), 2517-2528.

Xiao, S., Li, A., Jiang, F., Li, T., Wan, S., Huang, P., 2004. The history of the Yangtze River entering sea since the last glacial maximum: a review and look forward. Journal of Coastal Research 20(2), 599-604.

Yang, C.S., Sun, J.S., 1988. Tidal sand ridges on the East China Sea shelf. In: de Boer, P.L., van Gelder, A., Nio, S.D. (Eds.), Tide-Influenced Sedimentary Environments and Facies. D. Reidel Publishing Company, Dordrecht, pp. 23-38.

Yang W.D., 2002. Structure and sedimentary environment for submarine dune ridges in the East China Sea. Marine Geology \& Quaternary Geology 22 (1), 9-16. (in Chinese)

Yoo, D.G., Lee, C.W., Kim, S.P., Jin, J.H., Kim, J.K., Han, H.C., 2002. Late Quaternary transgressive and highstand systems tracts in the northern East China Sea mid-shelf. Marine Geology 187 (3-4), 313-328. 


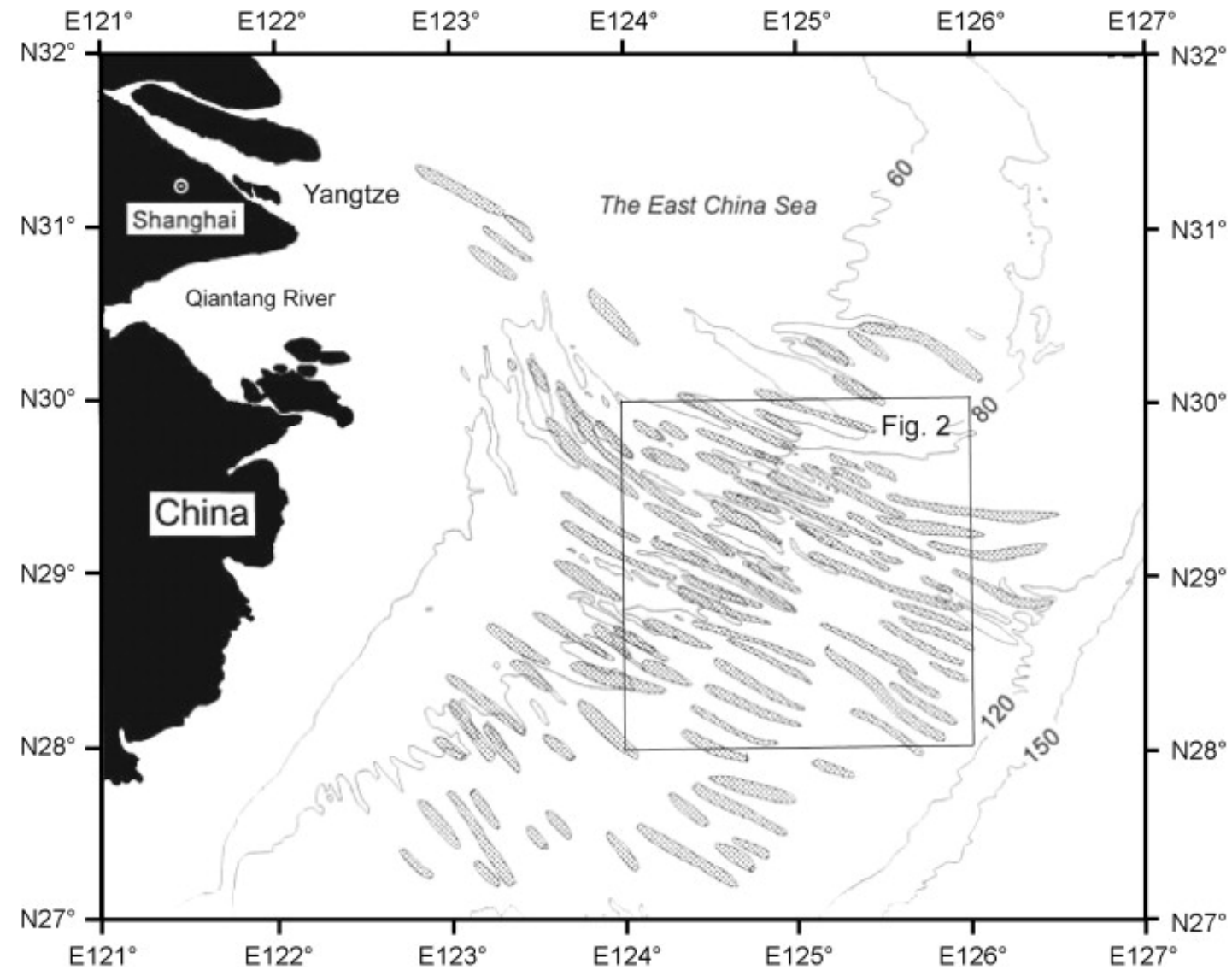

Fig. 1. Distribution of tidal sand ridges on the continental shelf in the East China Sea.

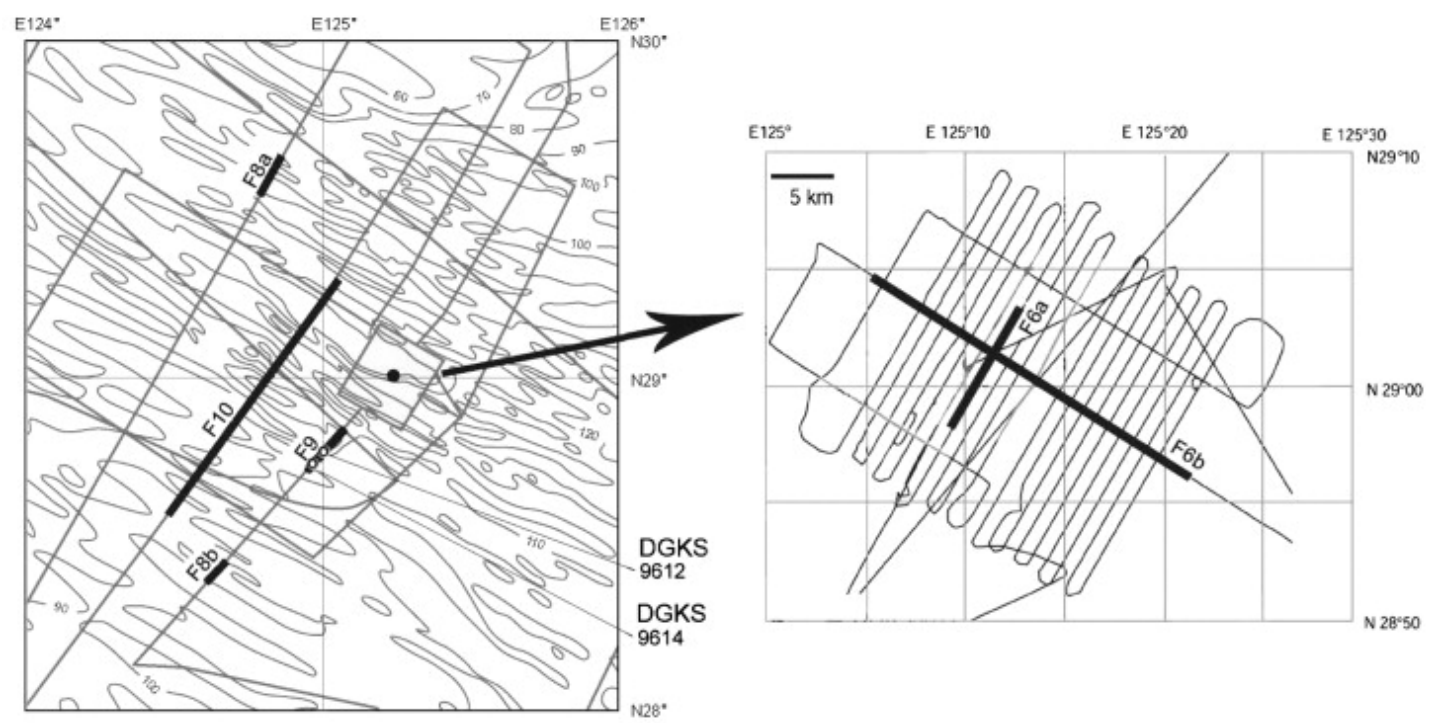

Fig. 2. Map of multibeam and seismic track lines on the continental shelf of the ECS obtained during the Chinese-French collaboration in 1996. Open circles are the locations of the piston cores DGKS9614 and DGKS9612. Bathymetry is shown in meters. The location of the ADCP survey done from the R/V L'Atalante is shown as a solid circle in the high-resolution survey area. 
a
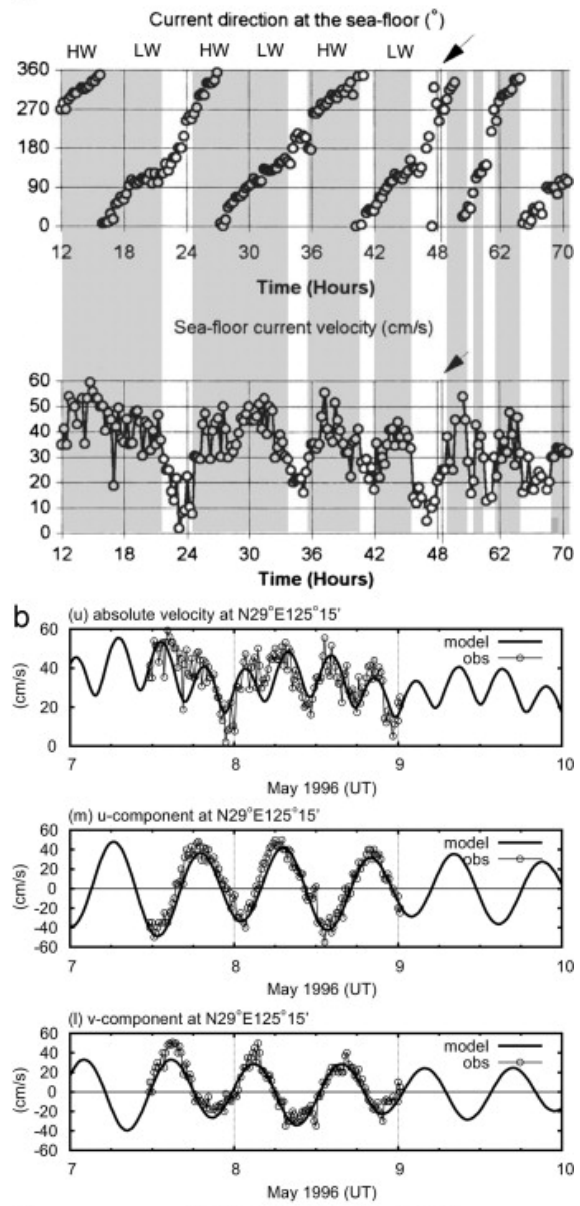

C

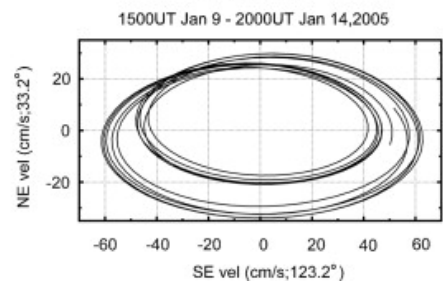

Fig. 3a. ADCP measurements of the Chinese-French investigation of the ECS (center: $29^{\circ} \mathrm{N}$, $125^{\circ} 15^{\prime} \mathrm{E}$ ). The upper diagram shows the current direction at $1 \mathrm{~m}$ above the seafloor, and the lower diagram shows the current velocity in $\mathrm{cm} / \mathrm{s}$ at $1 \mathrm{~m}$ above the seafloor (Berné, 1996). HW, high water; LW, low water. Shaded zones indicate periods when the velocity was more than 30 $\mathrm{cm} / \mathrm{s}$. Arrows indicate gaps in the measurements. The location where the measurements were obtained is shown in Fig. 2.

Fig. 3b. Comparison of current velocities at $29^{\circ} \mathrm{N}, 125^{\circ} 15^{\prime} \mathrm{E}$, derived from a tidal model (thick solid line) and ship-mounted ADCP (thin lines with circles). (u: upper) Absolute velocity; (m: middle) Eastward velocity component; and (l: lower) Northward velocity components. At this location, the semi-major axis of the $\mathrm{M}_{2}$ current ellipse is predicted to be $38 \mathrm{~cm} / \mathrm{s}$ in magnitude and $123.2^{\circ}$ clockwise from the north in direction.

Fig. 3c. A typical temporal change of the predicted tidal-current vector at $29^{\circ} \mathrm{N}, 125^{\circ} 15^{\prime} \mathrm{E}$ during a spring tide period (9-14 January 2005). The $x(y)$ axis was rotated clockwise by $33.2^{\circ}$ from the east (north) to align it with the direction of the major (minor) axis of the $\mathrm{M}_{2}$ current ellipse. 


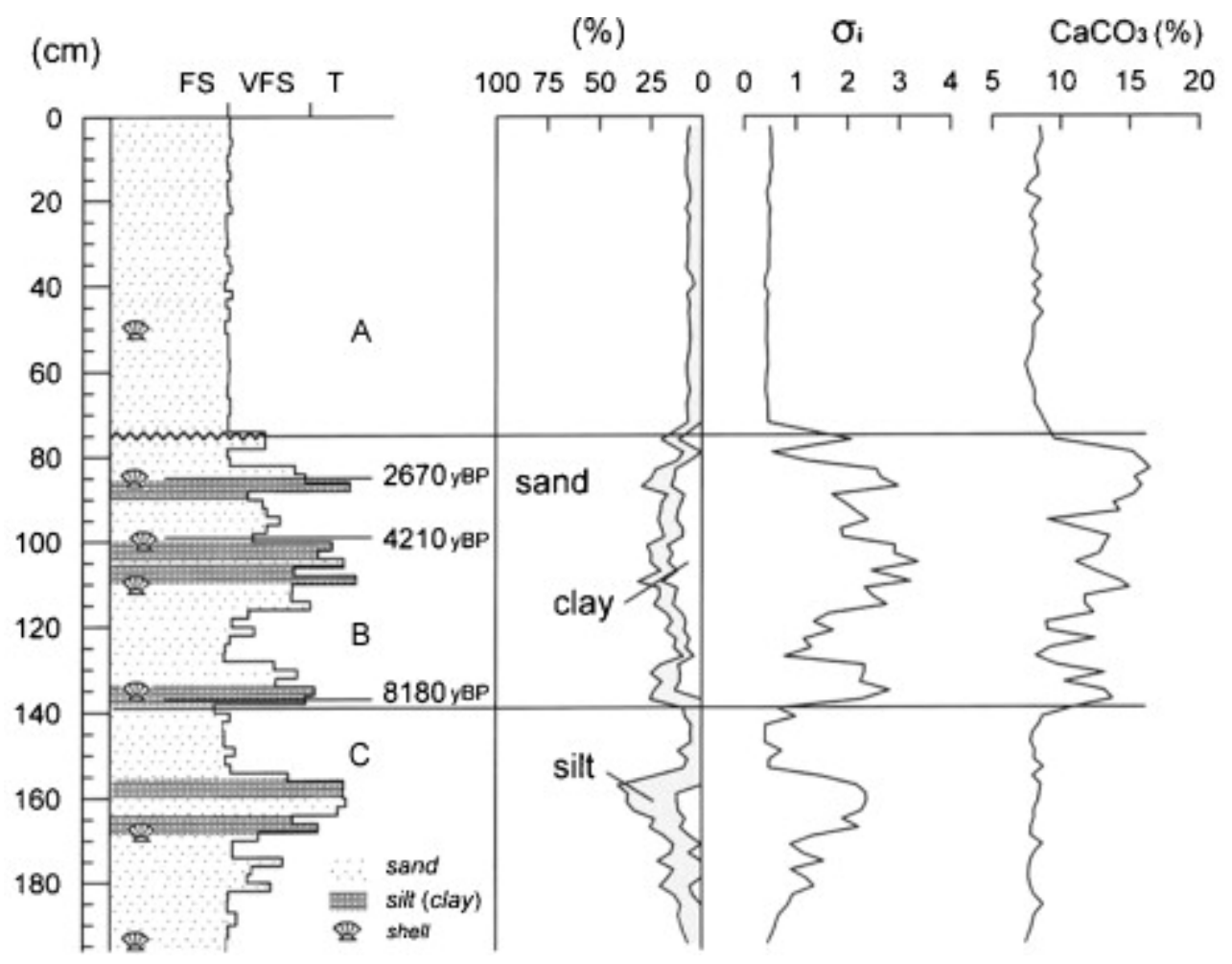

Fig. 4. The lithology of piston core DGKS9614 shows layers A, B, and C from top to bottom. FS, fine sand; VFS, very fine sand; $T$, silt. $\sigma 1$, sorting of grain size.

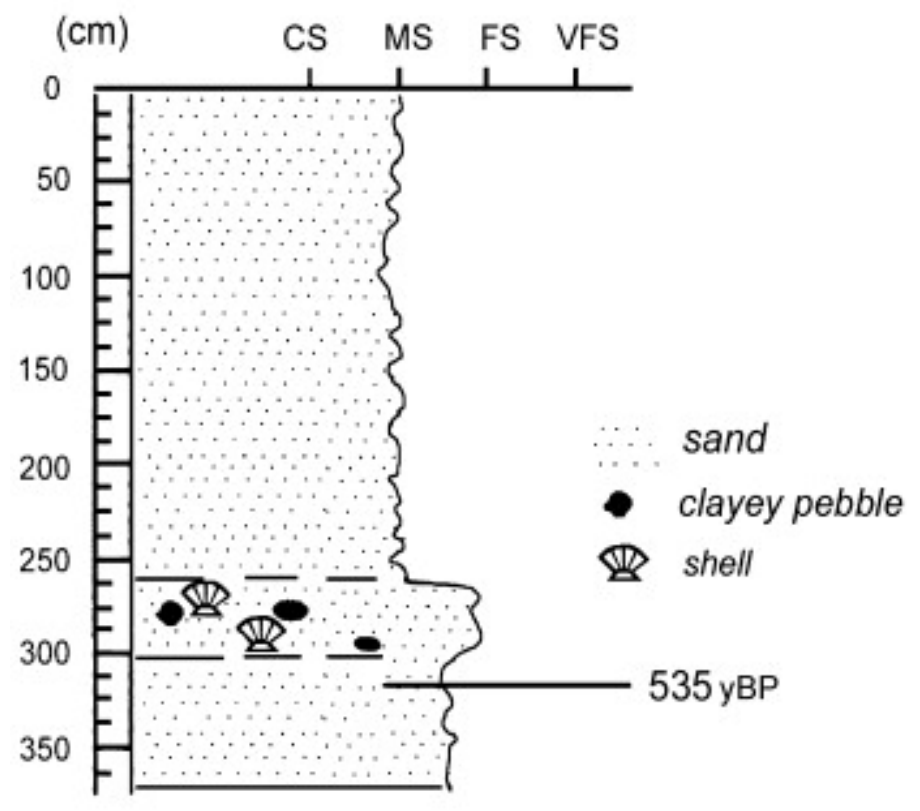

Fig. 5. The lithology of core DGKS9612. CS, coarse sand; MS, medium sand; FS, fine sand; VFS, very fine sand. 


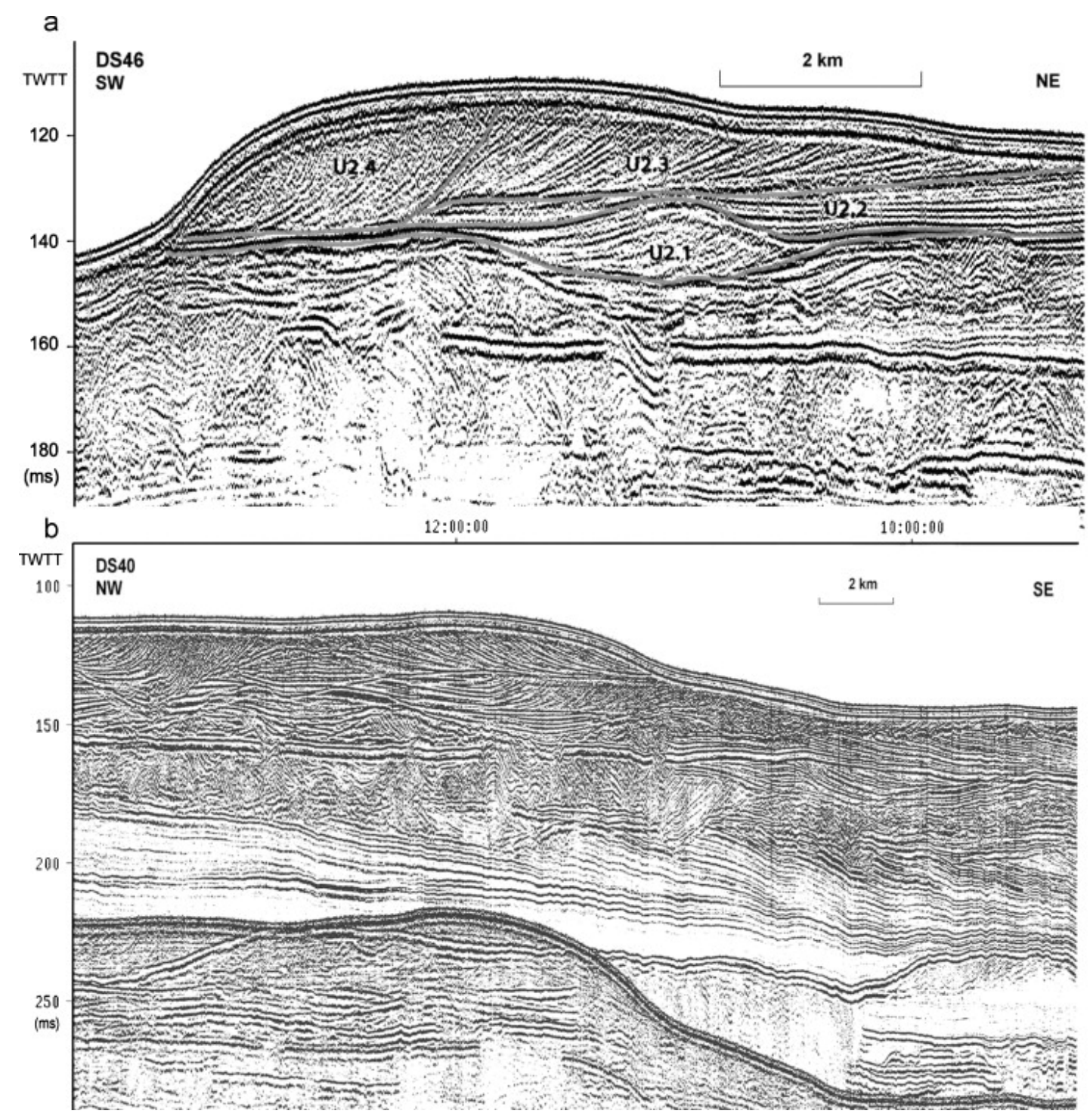

Fig. 6. Seismic records of sand ridges: (a) Subunits of sand ridges in transverse profile DS46. (b) Longitudinal seismic profile DS40 (in the direction of sand ridge extension). Locations are shown in Fig. 2. The vertical coordinate is two-way travel time (TWTT) (ms). 


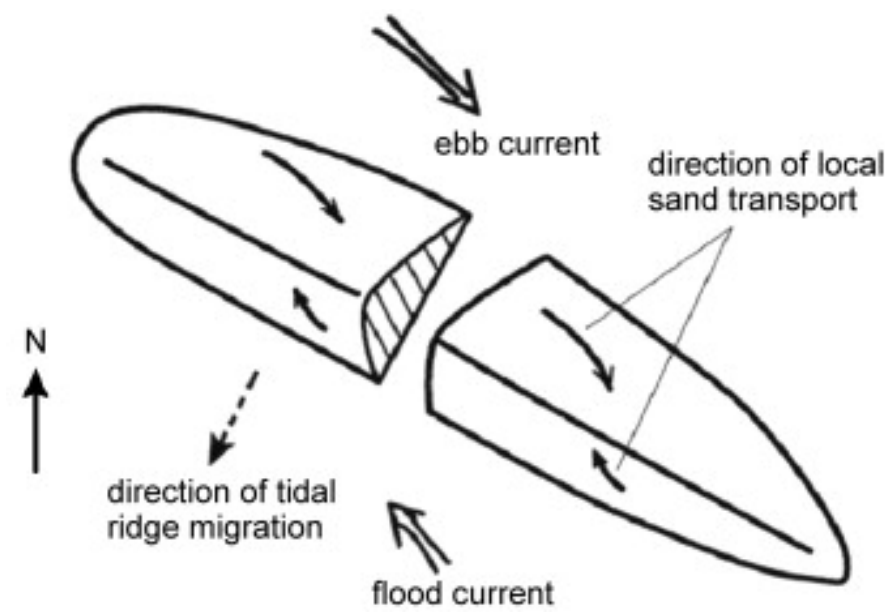

Fig. 7. Block diagram of tidal current and sand movement over a tidal sand ridge in the ECS. Note that the dip of the master bedding is parallel to the steeper slope of the ridge in the transverse profile. (Modified from Kenyon et al., 1981) 


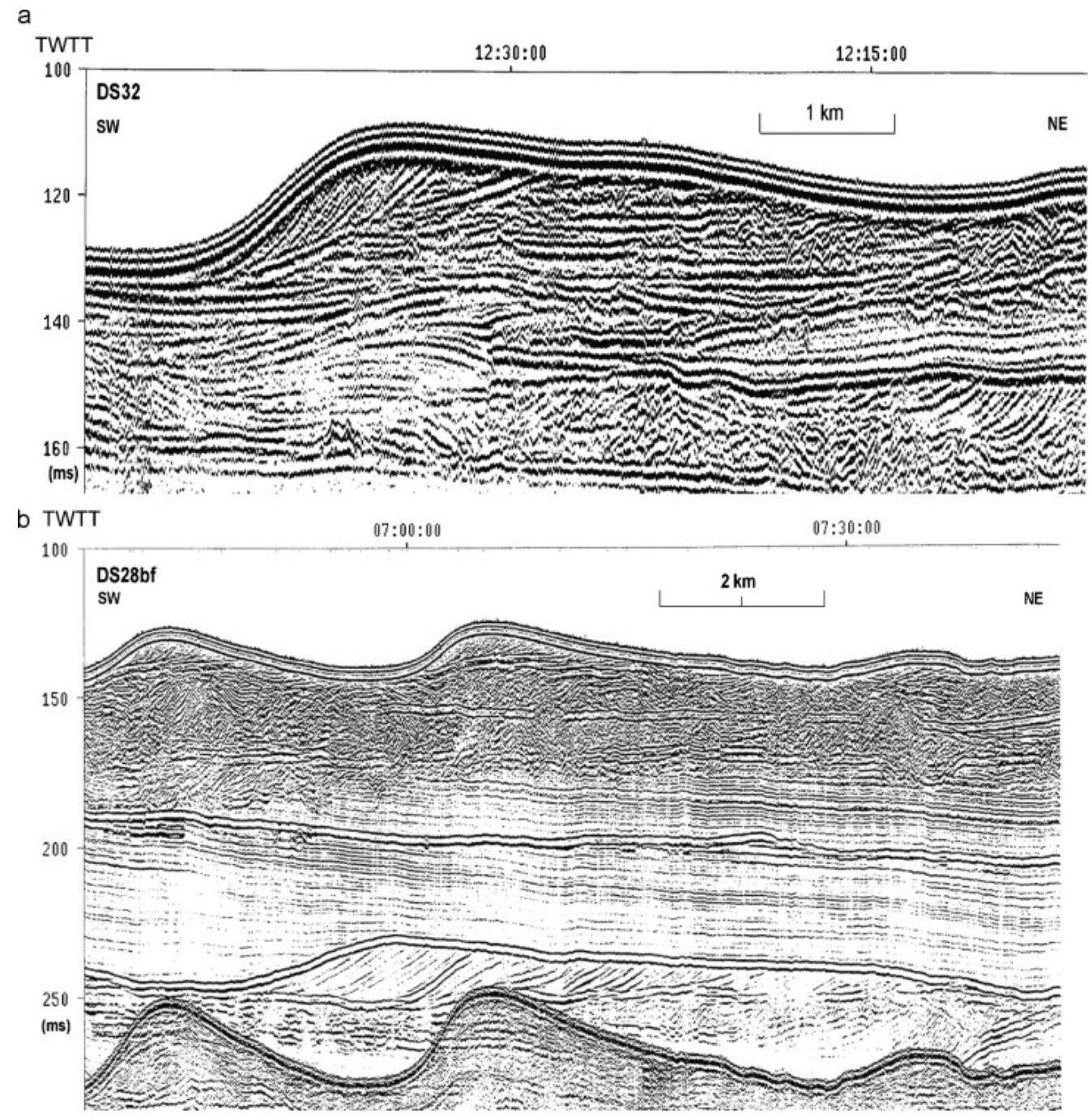

Fig. 8. Depositional-erosional tidal sand ridges on the continental shelf of ECS (transverse profiles: a, DS32; b, DS28bs), which show erosion obviously by tidal current. Locations are shown in Fig. 2. The material may have come from the redeposition of old fluvial or deltaic sediments. The vertical coordinate is two-way travel time (TWTT) (ms). 


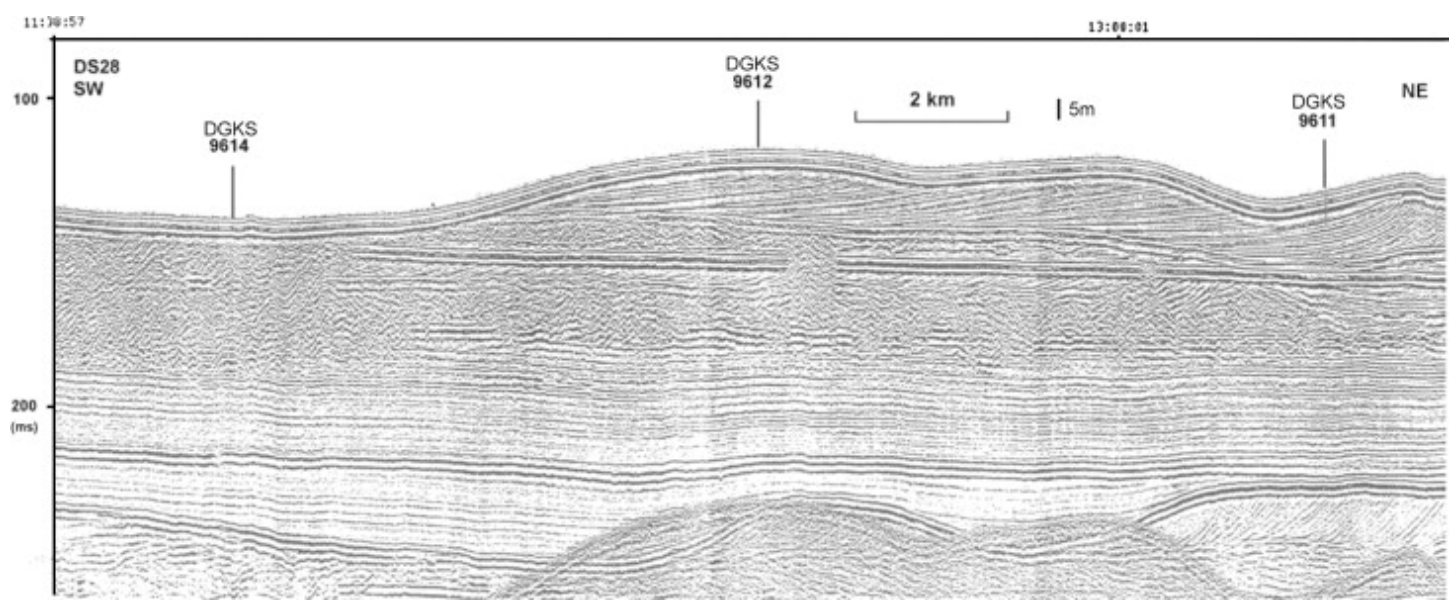

Fig. 9. Seismic profile DS28 and the locations of piston cores DGKS9614 and DGKS9612 (locations are also shown in Fig. 2). The vertical coordinate is two-way travel time (TWTT) (ms).

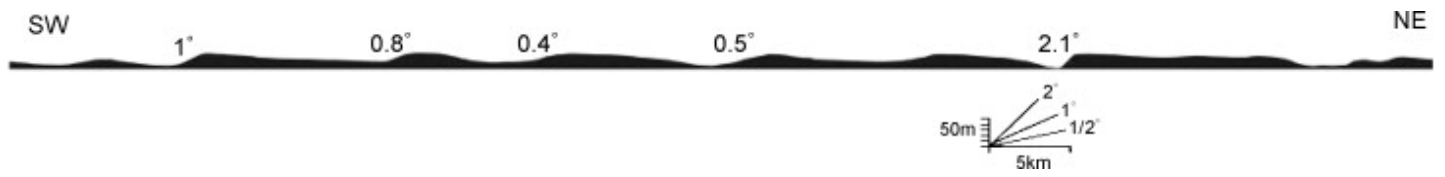

Fig. 10. Configuration of the ridges along seismic line DS36 in the ECS (the location is shown in Fig. 2). 